\title{
Historical and Epistemological Ways of Rationality and Faith in the Search of Logos (from Antiquity to the Middle Ages)
}

\author{
Yurij V. Sobolev* \\ Reshetnev Siberian State University \\ of Science and Technology \\ 31 Krasnoyarskiy Rabochiy, Krasnoyarsk, \\ 660049, Russia
}

Received 15.01.2017, received in revised form 07.08.2017, accepted 12.08.2017

The article deals with the dynamics and specificity of the ways of rationality and faith in the period of Antiquity and the Middle Ages. Based on the works of M. Heidegger, S. Averintsev, P. Gaidenko, A. Losev and S. Trubetskoi, the types of two cultures are compared through understanding of the concept "logos"; the peculiarities of the design and the content specificity of the two leading epistemological units of European culture are revealed.

Keywords: Logos, rationality, rationalism, faith, ratio, mifos, eidos, God, Christ.

DOI: 10.17516/1997-1370-0133.

Research area: culturology.

\section{Introduction}

Today, at the beginning of the third millennium, the problem of rationality is extremely acute, and not only philosophical reflection brings it to the level of key problems of European culture. One can state with certainty that a sudden turn to the issue of the relationship between rationality and faith is not a consequence of the search for new theoretical horizons of the problem, but this is a question posed by life itself, and therefore the relevance of the problem is of a practical nature. What was the reason for the explosion of interest in rationality? According to the philosopher P. Gaidenko, "the urgency of the problem of rationality is caused by the growing concern about the fate of modern civilization as a whole, not to mention the further prospects of science and technology development. The crises caused by the technotronic civilization, and above all the ecological one, are what ultimately is behind such a widespread interest in the problem of rationality" (Gaidenko, 2003: 9).

In the history of Western European philosophy, "rationality" is inevitably connected with "common sense" and "rationalism" - not just concepts expressing the doctrinal pathos of the new European era, but the phenomena that cement the cultural and historical core of the entire European

(C) Siberian Federal University. All rights reserved

* Corresponding author E-mail address: ysob@mail.ru 
paradigm. They can be rightly considered the ones to determine the logic of European culture from antiquity to our days. And therefore one of the main tasks, within the framework of our research, will be not just the conscious avoidance of equating these concepts, but, moreover, their distinction, while their correlation has deep roots in the historical and cultural field. What is the need to determine the place of the "watershed" in this issue? Academician S. Averintsev justifies the importance of distinguishing the concepts "rationalism" and "rationality" as follows: "I would like to distinguish this concept as sharply as possible (rationalism - author's italics, Yu.S.) within my materials from other concepts, primarily from the concept rationality as the feature of homo sapiens, from rationality and intelligence inherent in the Homer's Odyssey, because it seems to me extremely important that the transition from rationality to rationalism, i.e. from unformalized rationality to formalized, from rationality as the feature of homo sapiens to the formation of the technique of selfexamination of thought, when there are such things as epistemological problems, rules of logic, etc. - that this transition is in no way smooth and cannot be described as evolution" (Averintsev, 1989: 332-342).

Faith is a concept even less definite than "rationality" despite more evident lexical difference. The problem of the term is seen in its extreme "blurriness", which is present both phases of its existence at the same time - religious and everyday. Therefore, for example, scientists are considered to deny faith (it is not about their personal religiousness) in their professional activities in any form; but a religious person who somehow relates his/her life to otherness, is given a public credit of doubt in epistemological "security" and common sense. Unfortunately, such a stable culturological opposition deprives the possibility of reasonable analysis, and yet psychological studies of this issue remove the cliched covers from it explaining that faith is "a special phenomenon, since it is neither a process, nor a phenomenon, nor a state. Faith is not limited to religious faith, but acts as the basis of rational thinking of a person (and in this it comes close to knowledge)" (Maikova, 2010: 315-319).

\section{Statement of the Problem}

Now let us pay attention to the etymological secondary character of the concept "rationality", since the Latin word ratio is nothing but a free loan word from the Greek word logos introduced by Cicero. This circumstance makes the interpretation of the logos inevitable and important for understanding the original ways of rationality interwoven with the subsequent numerous historical and cultural inclusions. Continuing the etymological digression, it is worth pointing to the circumstance that the logos as a conceptual unit is not reducible to a single semantic "anchor"; in the authoritative Greek dictionary of I. Dvoretskii, the word $\lambda$ ó $\gamma$ o $\varsigma$ has 34 meaning groups, and this group, to some extent, is seen as a necessary addition to the value of the first one.

But what is the logos in the cosmic order of ancient Greek existence? As the Russian philosopher S.N. Trubetskoi, in his fundamental work devoted to logos (The Teaching on the Logos in Its History, 1906), the term occurs several times already in Homer's works, but in contrast to "mythos", "logos" in the Homeric epic is used in depreciatory meaning, such as: something dubious, evil, which one should not trust. However, Trubetskoi continues, "little by little this attitude changes radically: the "logos" takes precedence over "myth" or "epic". The myth from a "story" turns into a "legend" or a "fairy tale" and is opposed to the true word logos; "epic" in turn becomes a talk, a rumor, a saying, i.e. those words in which speech is put, 
sometimes for its decoration, sometimes in order to hide its true meaning" (Trubetskoi, 2000: 20).

It is worth pointing out a non-random conjugation of the mythos and the logos (the very name "mythology" underlines the dialectical nature of the phenomenon) in ancient culture. Explaining the meaning of the title of this section, let us refer to the symbolic conception of the myth by A. Losev, which asserts that the myth is ontologically rooted both in man and in the public consciousness. Thus, the myth according to Losev is the same eidos (logically constructed): the eidos is an ontological essential force; the logos is a methodological and instrumental design of the eidos. Hierarchically it is built as follows: logos of eidos, logos of logos, logos of meon, logos of sophia, logos of energy. Identification and, at the same time, distinction of the eidos and the logos by Losev is explained quite clearly: "The eidos and the logos are a kingdom of non-flowing and self-identical meaning" (Losev, 1999: 187); “The logos, or logical construction, the eidos gave us dialectics" (Losev, 1999: 187); "The logos of the expression of the eidos is the subject of aesthetics, and the logos of the expression of the logos is the subject of grammar" (Losev, 1999: 183). As there is no doubt that poetry and prose are literature that differ in expressive means, so the eidos and the logos, according to Losev's thought, should be considered the same way (by the way, the philosopher illustrates his arguments on examples of philology). That is why there is no contradiction in the words of S. Trubetskoi: “... in the period of intellectual maturity, the myth departs entirely to the field of tradition, poetry or fiction. The myth, which was once true, turns into a "false talk imitating the truth" or already into a poetic plot, a fable (e.g. "myths" of Aesop). The former usage remains partly in the works of tragedians, in poetry. The logographer is primarily a prose writer in contrast to a poet "aeda": the first Greek "logographers" are the most ancient historians from Cadmus and Hecataeus of Miletus to Herodotus, who wrote the history in prose in contrast to the poetic form of the myth used by epic poets. The mythological world outlook of poetry was replaced by the sensible prose" (Trubetskoi, 2000: 21).

The ambiguity of interpreting the word "logos" can already be found in the doctrine of the pre-Socratic philosophers. Let us start with the fact that the teaching of logos attributed to Heraclitus (namely, the teaching!) is highly doubtful, since the fragmentary nature of the philosopher's heritage does not allow one to unambiguously judge "logos" as a kind of "comprehensive mind", and it may well be that Heraclitus used this term purely technically, contextually denoting a measure, a word or a speech with. This is confirmed by the sarcastic genius of the twentieth century M. Heidegger ("Heraclitus' Teaching of the Logos, 1944"): "But what is "Logos"? Heraclitus does not say this - in none of the utterances that have come down to us" (Heidegger, 2011: 30). However, further Heidegger gives a detailed explanation: "Nevertheless, we need to remember well that $\lambda$ ó $\gamma \circ$ s is not a "word", not a "speech" and not a "language". This is clear from the fact that the main meaning of this Greek word can in no way imply anything like "speech" and "language", and does not contain any hint of anything linguistic and similar to language. Though on the other hand, it is indisputable that $\lambda$ ó $\gamma$ os and the associated verb $\lambda \varepsilon \dot{\gamma \varepsilon ı v}$ are quite early used by the Greeks in the sense of "talking", "saying". These are two indisputable facts that should be accepted. There is something mysterious in their neighbourship with each other" (Heidegger, 2011: 294). Defining Heraclitus' Logos by means of the triad: "One and All", "gathering and accumulation", "the name of being", Heidegger clarifies the key thing: "Logos is something audible, something like speech and voice, but apparently not the voice 
of a person voicing, announcing his speech" (Heidegger, 2011: 300). Let us complement this thought with another important place in which the German thinker discovers the "second bottom" of the usual concept, relating the logos to the eidos (in essence, we again meet the thought that was previously discovered in A. Losev's work):

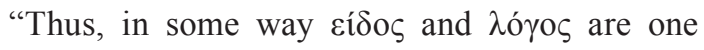
and the same. In other words, $\lambda$ ó $\gamma$ os understood as naming and saying, is comprehended in

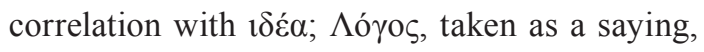
is that understanding of the "logos" that moves in the circle of thinking, thinking of what exists from ideas, that is, metaphysically, $\lambda$ ó $\gamma \circ$ conceivable by logic, is $\lambda$ ó $\gamma$ os, which is thought metaphysically. Logic is the metaphysics of the "logos" (Heidegger, 2011: 312).

Another interpretation of the "logos" was suggested by the representatives of the Eleatic school. Parmenides and his disciples believed that phenomena cannot be identified with the absolutely existing (logos). The eleates first contrasted the abstract thought (the logos as "a word about the existing") to the reality (visibility, dox). S. Trubetskoi writes: "He (the philosopher) comes to it (logos) from consideration of the external nature, and not from the analysis of logical processes. Thus, in the earliest period of Greek philosophy, the term logos has a vacillating meaning. It means mainly the reasoning in both the objective and the subjective sense. The nature of things is understood in reasoning, which is opposed to deceptive appearances; abstract thought embraces in itself the truth, from which the conclusion could subsequently come that this thought coincides with the truth or that truth is an idea. On the other hand, reasoning is the action of the human mind expressed in the speech or abilities of the human spirit - judiciousness" (Trubetskoi, 2000: 24). The continuation of this idea we find in the judgment of the domestic philosopher S. Neretina emphasizing that "ancient philosophy investigated the essence of things in themselves, independent of each other. The word was one of those things that had a strictly defined function. It also meant "a word spoken aloud", so it was especially important to find out the elusive speech connections, their logic (from the Greek logos - word, thought). This feature of ancient literature defined in many ways the open nature of education: through conversations and dialogues that took place somewhere in the bosom of nature, the feast-symposium" (Neretina, 1995: 15).

These are the first historical definitions of the logos - the rational beginning. As we see, already at the dawn of Greek philosophy there is no unambiguous understanding of the "logos":

- mythological intuition identifies the logos with the truth, but this identification is functional, since the logos is an intermediary: a reasonable carrier, but also a "crafty slave" of the truth;

- in the interpretations of the first philosophers, the logos is identified with either the inner law of being - the logos is the truth (the Heraclitus' line), or opposed to the phenomenon (the Parmenides' line). But in both cases, the preSocratic logos is the sounded being, the "essence of the ratio, the mind", the expression of the mind that fills the entire space of the cosmos: that is what we now call antique cosmo-logism - the rational binding uniting the physical and mental organics of the Ancient Hellas;

- early ancient philosophy does not know the rigid dichotomy of the logos and the eidos (mythos); it rather contains the intention of detecting the topos of the difference between them.

\section{Discussion}

Starting to review the situation of the Middle Ages, it is necessary to take into account a number of circumstances that should help us in an impartial analysis. 
First: the position that faith cannot have such properties as reliability and verifiability (the New European Mathesis universalis), and therefore cannot be worth of a serious study, is a scientific myth that gained popularity in the Age of Enlightenment. Unfortunately, it is often forgotten that the now-academic epistemological triad mind-belief-knowledge, receives the first outlines of its controversial design not in the $17^{\text {th }}$ century, but already in Antiquity (remember Parmenides)! And at the dawn of the Christian culture, it is the relationship between faith and reason that is brought into a question (the important fact is the fact of recognizing faith as an epistemological tool, and not ignoring it) within the limits of understanding in which we are up to this day. "Scientific knowledge is one of the aspects of cultural creativity, organically connected with other aspects influencing them and in turn experiencing their influence. Religion and philosophy have a particularly significant influence on the development of science, which in turn are deeply interrelated, although this connection is far from constant harmony. Science, originally emerged from the bosom of philosophy - it is enough to recall ancient science - is in the relation of attraction-repulsion with the religious consciousness of its time. This is quite understandable if we take into account that both philosophy and science are rational forms of cognition of the surrounding world and human experience, and therefore it is necessary to include a critical component. At the critical epochs of historical development, this component is often so intensified that sometimes a wrong idea arises about the polar opposition of the scientific and religious (and in some epochs, as, for example, in the $18^{\text {th }}$ century, even scientific and philosophical) consciousness, the belief arises that they mutually exclude each other" (Gaidenko, 2003: 150).
Second: (in the light of what was discussed above) the statement that at the junction of the age-old paradigms (the first centuries of AD), faith was strongly accepted as a universal or conventional source of truth, cannot be considered justified. If faith, according to the precise definition of the Russian philosopher V. Solov'iov, is "in the recognition of something true with such determination, which exceeds the force of external factual and formal logical evidence" (Solov'iov, 1896: 98), then how the resonance of the Thoughts of Tertullian $\left(2^{\text {nd }}\right.$ century) can be explained, which became known in the paraphrase "I believe, for it is absurd"? Evidently, the authority of the rational attitude in the Christian culture was high enough (despite the fundamental refusal of the sin-damaged mind as a gnoseological measure), although the question of its nature - inertial (borrowed from Antiquity) or immanent (a feature of the Christian doctrine) - remains open.

One thing is sure: the good news from Jerusalem - an event that changed the course and logic of the world history - the coming into the world of God and Savior Jesus of Nazareth, did not become a satisfactory answer to any of the questions of the ancient world from Heraclitus to Philo of Alexandria, but at the same time simultaneously solved them all. The Russian philosopher V. Losskii expressed this as follows: "Christianity frees a person from / ... / restrictions, revealing at the same time the fullness of the personal God and His nature. Thus, it completes the best of Israel and the best of other religions or metaphysical systems, and not in any syncretism, but in Christ and through Christ; indeed, in Him mankind is united with the Divine, and the Divine nature unites with the human nature in order to make it divine. This is the answer to Israel. But the Son is consubstantial with the Father and the Spirit, and this is the answer to impersonal metaphysical teachings. The divine nature is not 
"outside" the Person, on the contrary: the fullness of this nature is in the communion of the Divine Persons, and it is communicated to the person through personal communion" (Losskii, 1991: 4).

"And we preach Christ crucified, for the Jews a temptation, but for the Greeks madness" (1 Corinthians 1:23), writes the Apostle Paul in his Epistle. The words of the Apostle surprisingly accurately express the essence of the existing spiritual conflict, the conflict of religious law, rationality and ... faith (for more details see: Gal. 3: 23-26). For the first time in history, a clear call to faith - conscious and definite - arises precisely on the pages of the New Testament! The Jews who were "under the law" were waiting for the Messiah, the ideal ruler and savior of the nation, and the word "faith" did not know the place in the lexicon of the man of the Old Testament (it will be appropriate to note that in the Pentateuch of Moses the word "faith" never occurs!). The Greeks, whose consciousness was subordinated to the cyclical rhythmic Logos of Destiny (the well-known image of the wheel of Fortune), whose fatal predetermination was explained by the mind, appearing more as the "organizer" of the world's praxic order, also did not have a lacuna for the "light" of faith (at best, one can find an axiomatic assumption). Enlightened Rome, the fatherland of the genius of administration, was completely deprived of such claims, and even metaphysics was perceived by the patrician from the height of his classical education level as something scholarly, purely theoretical, the place of which is exclusively within the walls of philosophical schools (the sternly thrown replica of the prosecutor Pilate "What is truth?" (John 18:38) eloquently speaks for itself).

Jesus Christ is the Son of God, the Word of God (it was the logos that the early Christians preferred to call Christ, righteously avoiding the definition of the "Son" as one of the hypostases of God), which "became flesh", occupies a central place in the Christian dogma, being its most important spiritual focus. "God, speaking in the old days through the prophets, speaks in his Son - his true spiritual image. In his Son, in this perfect, intimate revelation of the heart of the Father, the Word of God is fulfilled, becomes man, becomes flesh: it is no longer an outer commandment or promise, not a law or prophecy, but full realization, the full incarnation of the Word of God, visible and tangible, alive. Such revelation and the realization of the Divine in the world is the ultimate goal for the sake of which the world has been created; this true goal of the world is its "logos" - its meaning and rational foundation. The "Son of God" is the alpha and omega, the first and the last, the Logos for the Hellenes and the final revelation of God, the Messiah for the Jews" (Trubetskoi, 2000: 218).

The paramount importance of identifying the "logos" and "Christ" is revealed quite accurately philologically. Another of the stable values of the "logos" ( $\lambda$ ó $\left.{ }_{0} \varsigma\right)$ is the concept of "teaching". Clarification of this nuance removes all possible historical and cultural covers from Christianity: Christ is the Teaching - "I am the way and the truth and the life" (John 14: 6). "Christianity is not conceivable without Christ (in spite of Baur, who wanted to explain the origin and essence of Christianity without Christ). In other religions, although the life and character of their founders are important, their personality is not so closely connected with the very idea of their religion as the person of Christ is associated with Christianity. / ... / Christianity is wholly built upon Him, is in the proper sense His creation, emerging from the depths of His Divine Spirit, and is fully embodied in the character of His Person. The personality of Christ is inseparably connected with the very essence of Christianity, for it is nothing but the teaching of what the Lord Jesus Christ taught and did. Hence, for a correct understanding of Christianity, it is necessary 
to study the Personality of Christ the Savior" (Bellavin, 1890: 177-201).

The experience of Christian theology put a person in front of a serious dilemma, before the "limit" of the logos - the Logos-Christ, uniting in himself two natures, revealing the Heavenly Kingdom of the earthly vale. One can say: the history of the Logos doctrine, which began in ancient Greece, ends in Jerusalem, ends in the incarnation in Christ, and this "incarnated Logos" becomes the evidence of the God-Man, which neither the religious nor the philosophical intellectual culture of antiquity could conceive and foresee. The French philosopher and theologian P. Teilhard de Chardin expressed this as follows: "To those who know Christianity only externally, it seems to be hopelessly overloaded with unnecessary details. In reality, taken in its main features, it contains an extremely simple and amazingly bold decision of the world" (Teilhard de Chardin, 2002: 420).

In this context, the dictate of a rational attitude ("the victory of the mind") looks very consistent in the subsequent transformation of the Evangelic message into an image of culture (more broadly, into a type of civilization); therefore, the first three centuries of the new era can be fully considered as a unique cultural "gap" between the end of the era of the logos and the beginning of the era of the ratio. In fact, could the first thinkers of Miletus and Elea or the wandering shramans of the Indian peninsula, who gave in to the impulse of a passionate avarice to intelligently understand the reality, assume that all the centuries-old potential of the mind accumulated under the shadow of wisdom would prove to be incapable, and not quite clever before the Face of the incarnate Truth? An excellent illustration of this is the famous parable "The Grand Inquisitor" by F. Dostoevsky, rare in the strength of its intention and embodiment, a work in which the protagonist is the personification of the rational yoke that dominates over man and rejects the truth that "disturbs" people in their established epistemological mechanics of predictability of the "reasonable" world order. "Without a firm idea of why he should live, a person will not agree to live and will sooner destroy himself than remain on earth, even though all around him were breads", the Inquisitor convinces his prisoner (Dostoevskii, 1973: 283). While blaming the interlocutor and insisting on his own rightness (we "corrected your feat"), the Jesuit cardinal - in the exposition of the philosopher V. Rozanov understands that "from this discrepancy of demands and abilities, ideal and reality, one must remain eternally unhappy: only few, strong in spirit, could and can be saved by following Christ and understanding the mystery of redemption. Thus, Christ, treating a person with such high respect, acted "as if not loving him at all". He did not calculate his nature and did something great and holy, but at the same time impossible, unrealizable"; "this is how this inexplicable and profound phenomenon happened in history, according to which "the poor have been deprived of and the rich have gained" (Rozanov, 1906: 109).

It is evidently obvious: popular since the Enlightenment, speculation on the "intolerant" confrontation, looks, in this light, not quite thorough, and the dilemma known to us today, another name of which is the confrontational idiom "science and religion", was generated precisely by the development of the doctrine that ended with "isolation" of this doctrine by rational systems of theology that occurred at the end of the Middle Ages (Renaissance) (therefore it is no coincidence that in its "birth certificate" the "cradleland" of the modern science is signified - Western Europe of the $16^{\text {th }}$ $17^{\text {th }}$ centuries!). But the precedent that provoked this epistemological battle was still there. And it was in an ordinary, at first glance, event - the 
formulation of direct inquiry of the relationship of faith and reason. If in the first centuries of the emergence of Christianity (and in the Greek-Byzantine tradition up to the $13^{\text {th }}-14^{\text {th }}$ centuries - the era of polemics of humanists and hesychasts), the question of the place of reason and its parity with faith was present only in the "natural setting" (in terms of phenomenological lexemes), the "era of learning" - scholasticism, putting a hard-hitting question, places this problem in the field of reflection. "Including" it into the action as an active object, marked the automatic loss of the status of "age" and the beginning of the claim to uniqueness, which ultimately resulted in the dominance, displacing other interaction objects to the periphery (this idea is brilliantly revealed in the semiotic theory in the works of the French philosopher R. Barth). Once in the sight of the intellectual analysis, the issue of "faith-and-reason" finally came under the pressure of the rational dominant-rationalism: "religious focus reveals restructuring of the theocentric view of the world into the anthropocentric "system of axes" with its empiricism, rationalism, sensationalism and subjectivism" (Evdokimtsev, 2008: 35-38).

Averintsev, a medieval expert, considering the character of the new European paradigm in his work "The Two Births of European Rationalism", masterfully recreating specific portraits of two types of rationality - the logicrhetorical type ("inherited by the Middle Ages from Antiquity") and the new European (devoid of "contemplative nature"), writes: "The rationalism that the Greeks created and which is already out of fashion of "scholasticism" lived out its time in the Modern Age, by its own internal principle, aimed at the unchanged balance between reflection and tradition, between criticism and authority, between physics and metaphysics. This is rationalism, which sets limits to itself, and not just accepts them according to circumstances from outside - say, from religious dogma. The breakthrough in the Modern Age of a different rationalism, fundamentally denying the boundaries, was, in our view, the end of stagnation, but from the point of view of the old rationalism, it was a violation of equilibrium and overturning of the rules. It is one and the same, no matter from what point of view we look. Not from the point of view of the natural science, but the general cultural one, the old rationalism had one advantage: it alone could create an image of the world that, unlike the incoherent mythological notions, is logical enough and not contradictory, and unlike the theories of the modern science, it is sufficiently stable and sensual enough to really be an image - an exciting topic for the imagination" (Averintsev, 1989: 3-13).

\section{Conclusion}

Thus, if we interpret the logos as a metaphysically-integral law taken as a necessary condition for an existentially balanced and thinking culture, then, applying it to known historical epochs, we find that, beginning in the Middle Ages, this law is gradually buried under the "new building" of the progressive educational thought of European figures. If one understands the logos in the spirit of the New Testament teaching as the God-man Jesus Christ, then first, in the face of scholasticism, "Christianity did not enter into the thought" (N. Berdiaev), and then the Reformation wave finally "washed" the logos from the new European life, putting it in the opposition to/outside the Church. To crown this thought, let us give a remark: close attention to the problem of faith and reason does not arise in the first centuries of the Christian era, nor does it arise at the dawn of ancient philosophy, which could be explained by the general principle of historical logic, but from the $17^{\text {th }}$ century onwards and to this day, this trend has no identity (however, the "vector" of the Enlightenment could not get 
rid of the burden of the historical memory of the logos - see works by non-classical thinkers S. Kierkegaard, A. Schopenhauer, F. Nietzsche). The era of one and a half thousand years of "cruising" around the logos ended with an "exit" beyond the known, though undiscovered, orbit. No wonder the German historian of philosophy Wilhelm Windelband thought that "the Middle Ages took the path that has been made by the Greeks in their internal relation to science, in the opposite direction" (Windelband, 1997: 222). This is partly why the pathos of Renaissance formally clothed in human garments, remained unrealized due to the inability to "self-revival", creating the "exhibits" alien to the intuition of the logos: "at first timidly and tentatively, then more and more assertive, again awakens the desire for the knowledge itself; it originally appears in those areas which are more remote from all the inviolable principles of faith, but in the end it breaks out uncontrollably in all spheres; science begins to separate from faith, philosophy from theology" (Windelband, 1997: 222).

Thus, looking at the picture of the decline of the Middle Ages, we are forced to diagnose the growing dictate of the cognitive attitude, what will later be called the new European rationalism.

Summarizing the above, it should be noted that:

\section{References}

Averintsev S. (1989). Dva rozhdeniia evropeiskogo ratsionalizma [Two births of the European rationalism]. In Voprosy filosofii [Philosophy issues], (3), 3-13.

Averintsev S. (1989). Dva rozhdeniia evropeiskogo ratsionalizma. Chelovek v sisteme nauk [Two births of the European rationalism.The person in system of sciences]. Moscow, 332-342.

Bellavin V. (1890). O litse Gospoda Iisusa Hrista [About the person of God Jesus Christ]. In Strannik, V. II.177-201.

Gaidenko P.P. (2003). Nauchnaia ratsional'nost' i filosofskii razum [Scientific rationality and scientific reason]. Moscow, Progress-Traditsia Publ, 528 p.

Dostoievskii F. (1973). Brat'ia Karamazovi [Brothers Karamazov]. Moscow, Hudozhestvennaia literatura Publ, 853 p. 
Evdokimtsev D.V. (2008). Ot Srednevekov'ia k Novomu vremeni: restrukturizatsia «real'nosti» i filosofskogo soznaniia [From the Middle Ages to the Modern Age: restructuring of "reality" and philosophical consciousness]. In Voprosy kul'turologii [The culturology issues], (9), 35-38.

Heidegger M. (2011). Geraklit [Heraclitus]. St. Petersburg, Vladimir Dal' Publ. 512 p.

Losev A.F. (1999). Filosofia imeni / Samoe samo: Sochineniia [Name philosophy / the Most: Compositions]. Moscow, Eksmo-Press, 1024 p.

Losskii V. (1991). Dogmaticheskoe bogoslovie [Dogmatic Theology]. Moscow, Tsentr «SEI», 1991. 289 p.

Maikova J.A. (2010). Predikati very [Belief predicates]. In Vestnik Bashkirskogo universiteta [Bulletin of Bashkir State University], V. 15 (2), 315-319.

Neretina S.S. (1995). Veruiushii razum [The believing reason]. Arhangel'sk, Pomorskii peduniversitet Publ., 320 p.

Rozanov V. (1906). O legende «Velikii inkvizitor» [About the legend "The Great Inquisitor”]. St. Petersburg, PetrGY Publ, 266 p.

Solov'iov V.S. (1896). Vera [Belief]. In Entsiklopedicheskii slovar' Brokgauza i Efrona [Brockhaus and Efron's encyclopedic dictionary]. St. Petersburg, V. 6. p. 98.

Teilhard de Chardin. (2002). Fenomen cheloveka: Sb. Ocherkov i esse [Phenomenon of the person: collection of sketches and articles]. Moscow, AST Publ, $553 \mathrm{p}$.

Trubetskoi S.N. (2000). Uchenie o logose v ego istorii [The doctrine about Lagos in its stories]. Moscow, AST Publ: Har'kov Folio Publ, 493 p.

Windelband V. (1997). Istoriia filosofii [Philosophy history]. Kiev, Nika-Tsentr Publ, 560 p.

\section{Историко-гносеологические пути рациональности}

\section{и веры в поисках логоса}

(от Античности до Средневековья)

Ю.В. Соболев

Сибирский государственный университет науки и технологий имени академика М.Ф. Решетнева

Россия, 660000, Красноярск,

пр. им. газ. «Красноярский рабочий», 31

\footnotetext{
В статье рассматривается динамика и специфика путей рациональности и веры в период Античности и Средневековья. Опираясь на труды М. Хайдеггера, С. Аверинцева, П. Гайденко, А. Лосева, С. Трубеикого сопоставляются типь двух культур через осмысление понятия «логос»; выявляются особенности оформления и содержательная спещифика двух ведущих гносеологем европейской культуры.
}

Ключевые слова: логос, рачиональность, рационализм, вера, рацио, мифос, эйдос, Бог, Христос. Научная специальность: 24.00.00 - культурология. 